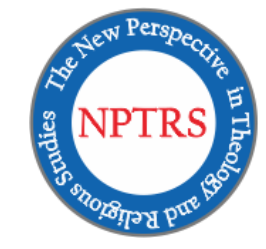

The New Perspective in Theology and Religious Studies

Vol. 2, No. 1 (2021):1-25

http://journalsttcipanas.ac.id/index.php/NPTRS/

p-ISSN 2722-9726, e-ISSN 2722-9718

Published by Cipanas Theological Seminary

\title{
Menggunakan Logika Sente(n)sial untuk Memahami Yesus sebagai (Sang) \\ Manunggaling Kawula Gusti: Suatu Awal Penelusuran
}

\author{
Robby Igusti Chandra \\ Email: robbycha@yahoo.com \\ Victor Christianto \\ Email: victorchristianto@gmail.com
}

\begin{abstract}
This article explores the Aristotelian logic and the sentential logic in explaining Jesus Christ as described in Manunggaling Kawula Gusti concept. First, it studies the dimensions of Jesus as the manifestation of manunggaling kawula, a concept that roots in Kejawen spirituality. Second, to analyze the feature of divinity-humanity union in Manunggaling Kawula Gusti compared with the western Christian view of Jesus Christ. Third, the article explores whether the sentential logic explains Kawula Manunggaling Gusti more clearly than The Aristotelian or either-or logic. The hypothesis is that the Aristotelian logic is less adequate to explain the concept of Jesus as Manunggaling Kawula Gusti in comparison with sentential logic as the latter consists of betweenness, neitherness, or bothness concept. The method in this study is qualitative research consists of textual interpretation and philosophical logic analysis. As the result, it proves that the sentential logic can explain better the union between the humanity and divinity of Christ both in the concept of Manunggalung Kawula Gusti and in western Christian view as well compared to the either-or logic. The result is useful to enrich dialogue or contextualization process with people who are accustomed to the neither-nor or both as-well as logic as used amomg the Javanese.
\end{abstract}

Keywords: Aristotelian logic. sentential logic, Unio Mystica, Kejawen, Manunggaling Kawula Gusti, Jesus, contextualization 


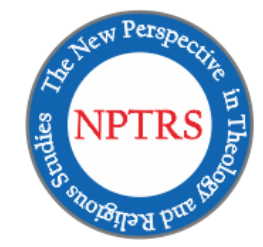

The New Perspective in Theology and Religious Studies

Vol. 2, No. 1 (2021):1-25

http://journalsttcipanas.ac.id/index.php/NPTRS/

p-ISSN 2722-9726, e-ISSN 2722-9718

Published by Cipanas Theological Seminary

\begin{abstract}
Abstrak
Artikel ini menelusuri penggunaan konsep logika Aristotelian yaotu either-or atau logika dualis dibandingkan dengan penggunaan logika sentensial untuk menjelaskan kesatuan hakekat kemanusiaan dan keilahian dalam diri Kristus yang termuat dalam konsep Manunggaling Kawula Gusti dari Budaya Jawa. Pertama, artikel akan meneliti dimensi-dimensi mengenai kestauan manusia-ilahi dalam diri Yesus dalam konsep manunggaling kawula gusti yang berasal dari konsep spiritualitas Kejawen. Kedua, akan dibandingkan fitur penyatuan keilahian dan kamanusiaan Kristus dalam Manunggaling Kawula Gusti dan pandangan teologi Kristen Barat pada umumnya. Ketiga, artikel ini meneliti bagaiman logika sentensial dapat menjelaskan Kawula Manunggaling Gusti dengan lebih rinci dibandingkan dengan logika either-or. Hipotesis yang diajukan adalah bahwa logika sentensial lebih efektif menjelaskannya karena, dalam konsep dan alatnya terdapat konsep "antara", "bukan ini atau itu," dan "ini serta itu." Metode yang dipergunakan dalam studi ini adalah riset kualitatif berupa tafsir teks dan eksplorasi filosofi logika. Sebagai hasilnya, terbukti bahwa dengan menggunakan logika sentensial, penyatuan antara kemanusiaan dan keilahian Kristus dalam konsep Manunggaling Kawula Gusti dapat lebih dijelaskan dan masuk akal. Hasil ini berguna untuk memperkaya proses dialog atau kontekstualisasi ke dalam Budaya yang terbiasa dengan logika non dualis dan konsep Manunggaling Kawula Gusti seperti Budaya Jawa.
\end{abstract}

Keywords: Logika sentensia, Kejawen, Manunggaling Kawula Gusti, Yesus, kontekstualisasi.

\title{
Pendahuluan
}

Salah satu kekayaan budaya dan spiritualitas Indonesia adalah adanya kepercayaan local yang dikenal dengan nama penghayat, atau kebathinan atau Kejawen yang jumlah penganutnya adalah sekitar 12 juta orang ${ }^{1}$. Membuat interpretasi yang tepat mengenai paham kalangan Kejawen atau berdialog dengan mereka seringkali sulit karena, ajaran dan teks mereka sarat

\footnotetext{
${ }^{1}$ David Saut, “Ada 187 Organisasi Dan 12 Juta Penghayat Kepercayaan Di Indonesia,” Detiknews, November 9, 2017,https://news.detik.com/berita/d-3720357/ada-187-organisasi-dan-12-juta-penghayat-kepercayaan-diindonesia.
} 


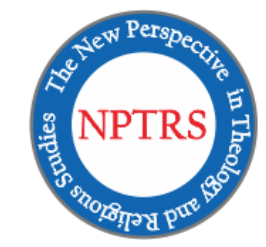

The New Perspective in Theology and Religious Studies

Vol. 2, No. 1 (2021):1-25

http://journalsttcipanas.ac.id/index.php/NPTRS/

p-ISSN 2722-9726, e-ISSN 2722-9718

Published by Cipanas Theological Seminary

dengan istilah abstrak yang multi-tafsir dan bagi banyak orang logikanya sulit ditangkap. Kemudian, teks-teks Kejawen yang mereka hasilkan juga penuh dengan ungkapan-ungkapan dialektis. Hal ini bagi kalangan terbiasa dengan logika Aristoteles yang dikenal dengan nama logika katergorikal, biner, dualis atau either-or terasa rumit. Kesulitan di atas sering mengakibatkan para pakar Barat di masa lalu memberikan pandangan negatif mengenai logika Kejawen dan berbagai teks kunonya. Bahkan ada yang menyamakan teks-teks itu dengan tulisan primbon, aji-ajian, mantera, dan sebagainya seperti pandangan misionari di masa lalu.

Salah satu suara penting dari kepercayaan rakyat di Jawa yang menganut spiritualitas Kejawen terwakilkan dalam konsep yang dikenal dengan Manunggaling Kawula Gusti atau menyatunya diri manusia dengan Yang Ilahi. Konsep ini merupakan suatu spiritualitas yang operatf yang berarti diterapkan ke dalam hidup sehari-hari berbagai tokoh sampai masa kini seperti dipaparkan oleh Hadiwijaya dalam buku Tokoh-tokoh Kejawen: Ajaran dan Pengaruhnya $^{2}$. Jadi, bagi para penganut Kejawen, Manunggaling Kawula Gusti inilah yang menjadi tujuan hidup yaitu mencapai penyatuan diri dengan sang Ilahi.

Bagi penganut Kejawen yang kemudian menerima iman Kristiani atau menggabungkan diri ke dalam gereja, maka mudah dipahami bahwa mereka memandang, sosok yang mengalami Manunggaling Kawula Gusti tersebut secara sempurna adalah Tuhan Yesus. Dasar pemikiran tersebut ada di dalam injil Yohanes pasal 1, dipaparkan bahwa, Yesus adalah Logos atau Firman Allah yang menjadi manusia ${ }^{3}$. Apalagi dicatat dalam Yohanes 10:30 bahwa, Ia sendiri mengatakan bahwa "Aku dan Bapa satu." Hal ini ditajamkan oleh budayawan dan pakar dalam kontekstualisasi Kristiani, Bambang Noorsena juga menyatakan bahwa Kristus adalah wujud manunggaling kawula Gusti tersebut ${ }^{4}$.

Tentunya beberapa pertanyaan muncul. Pertama, apakah arti konsep Jesus sebagai wujud manunggaling kawula Gusti yang berasal dari konsep spiritualitas Kejawen itu.

\footnotetext{
${ }^{2}$ Hadiwijaya, Tokoh-Tokoh Kejawen, 1st ed. (Yogyakarta: Eulo Book, 2010).

${ }^{3}$ Yohanes 1: 1-5, dan 9-10

${ }^{4}$ Bambang Noorsena, Menyongsong Sang Ratu Adil: Perjumpaan Iman Kristen Dan Kejawen, 1st ed. (Yogyakarta: Andy Offset, 2003). hal 17
} 


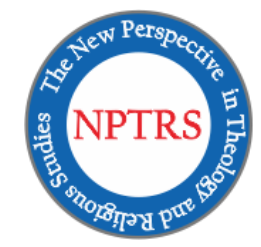

The New Perspective in Theology and Religious Studies

Vol. 2, No. 1 (2021):1-25

http://journalsttcipanas.ac.id/index.php/NPTRS/

p-ISSN 2722-9726, e-ISSN 2722-9718

Published by Cipanas Theological Seminary

Kedua, dapatkah logika sentensial menjelaskan Kawula Manunggaling Gusti tersebut dengan lebih baik dibandingkan dengan logika Aristoteles yang dikenal dengan nama categorical logic yang bertumpu pada pendekatan either or atau logika biner.

Hipotesis yang diajukan adalah bahwa logika sentensial lebih efektif untuk menjelaskan konsep Jesus sebagai wujud manunggaling kawula Gusti dengan baik karena logika ini mengandung konsep bukan ini-bukan ini serta konsep juga ini-dan juga itu.

Merujuk pada Gadamer sebagai dipaparkan oleh Darmaji, ${ }^{5}$ dialog antar iman atau keyakinan berguna untuk mengembangkan cakrawala pemikiran (horizon), maka tujuan penulisan ini adalah memperkaya proses dialog dengan meningkatkan pemahaman akan corak logika yang dipakai masing-masing pihak yang berdialog. Dengan cara menjelaskan logika sentensial, diharapkan artikel ini dapat memperluas horizon pemikiran, baik bagi teolog yang berusaha melakukan dialog iman untuk memahami mitra dialog dan menyeberangkan gagasan tentang Yesus Sang Mesias kepada umat di Nusantara, maupun para penganut Kejawen yang berusaha membagikan pemahaman dan pengalaman spiritual mereka.

\section{Metode}

Metode yang dipergunakan dalam penelusuran disini adalah bersifat kualitatif dan menganalisis muatan-muatan teks yang memaparkan konsep Kristen mengenai penyatuan di dalam Diri Kristus dan konsep manunggaling kawula gusti dalam kaitannya dengan Tuhan Yesus. Hal ini sejalan dengan prinsip-prinsip metodologi penelitian kualitatif, mengutip John Creswell: "Qualitative methods demonstrate a different approach to scholarly inquiry than methods of quantitative research. Although the processes are similar, qualitative methods rely on text and image data, have unique steps in data analysis, and draw on diverse designs." 6

Selanjutnya akan dibuat paparan mengenai logika Aristoteles yang dikenal dengan nama logika kategorikal yang berdasarkan pendekatan either-or atau biner (binary), dan kemudian logika sentensial. Juga akan dipaparkan kekuatan dan kelemahan logika Aristoteles yang either-

\footnotetext{
5 Agus Darmaji. Dasar-Dasar Ontologis Pemahaman Hermeneutik Hans-Georg Gadamer. Refeksi, Volume 13, Nomor 4, April 2013, hal. 469-494.

${ }^{6}$ John W. Creswell. Research Design, $4^{\text {th }}$ Edition. (Los Angeles: SAGE Publications, Inc, 2014)
} 


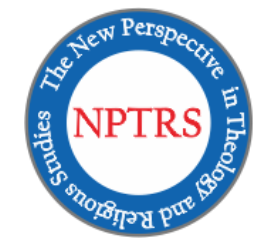

The New Perspective in Theology and Religious Studies

Vol. 2, No. 1 (2021):1-25

http://journalsttcipanas.ac.id/index.php/NPTRS/

p-ISSN 2722-9726, e-ISSN 2722-9718

Published by Cipanas Theological Seminary

or dibandingkan dengan logika sentensial. Secara khusus dengan penggunaan logika sentensial, khususnya instrument yang dikenal sebagai Truth Table (tabel-tabel kebenarannya) yang dipergunakan untuk menguji kebenaran suatu pernyataan akan dikaji dalam menjelaskan aspekaspek konsep kawula manunggaling Gusti.

Untuk tidak membebani para pembaca dengan detil logika sentensial maka dilakukan penyederhanaan sebagai contoh saja bagaimana suatu konsep yang abstrak dan rumit dapat diungkapkan melalui simbol-simbol logika ini secara terbatas untuk menunjukkan kekhasannya serta potensinya.

\section{Hasil dan Pembahasan}

\section{Pandangan penyatuan ilahi (Divine Communion) dalam Kristologi Barat}

Secara umum, di dalam iman Kristen diyakini bahwa, Yesus Kristus adalah sepenuhnya manusia dan sepenuhnya Allah. Substansi kemanusiaan dan substansi keilahian menyatu di dalam diri-Nya.

Para peneliti seperti Altmann menyebutkan bahwa, istilah penyatuan dimulai dari konsep yang dikenal dengan nama henosis dari masa Neoplatonis ${ }^{7}$. Asal penggunaan itu muncul ketika Philo dari Aleksandria (20 SM sd $50 \mathrm{M}$ ) menafsirkan istilah 'berpaut'

Bagi Philo, inti penyatuan dalam diri Kristus adalah penyatuan dua substansi karena cinta. Jadi inti dari unio mystika bagi Philo adalah keintiman dengan sang Ilahi. Gambaran yang digunakan adalah bagaikan seorang manusia berdiri di samping Allah sebagai kekasih-Nya. Dalam hal ini, terbaca bahwa, substansi manusia dan substansi Allah tetap hadir di dalam penyatuan atau Kesatuan tersebut.

Philo mendasarkan padangannya pada istilah keterpautan yang digunakan di Perjanjan Lama:

\footnotetext{
${ }^{7}$ Alexander Altmann, "Ibn Bajja on Man's Ultimate Felicity," in Studies in Religious Philosophy and Mysticism (Ithaca, NY: Cornell University Press, 1969), hal. 104
} 


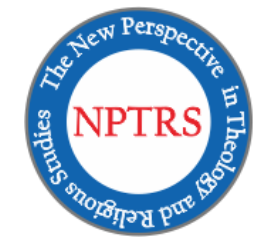

The New Perspective in Theology and Religious Studies

Vol. 2, No. 1 (2021):1-25

http://journalsttcipanas.ac.id/index.php/NPTRS/

p-ISSN 2722-9726, e-ISSN 2722-9718

Published by Cipanas Theological Seminary

1. Ulangan 10:20 Engkau harus takut akan TUHAN, Allahmu, kepada-Nya haruslah engkau beribadah dan berpaut, dan demi nama-Nya haruslah engkau bersumpah. Pandangan Philo mengenai istilah berpaut dengan Allah ini menjadi akar teologi mistisnya.

2. Ulangan 11:22 Sebab jika kamu sungguh-sungguh berpegang pada perintah yang kusampaikan kepadamu untuk dilakukan, dengan mengasihi TUHAN, Allahmu, dengan hidup menurut segala jalan yang ditunjukkan-Nya dan dengan berpaut pada-Nya,

3. Ulangan 13:4 TUHAN, Allahmu, harus kamu ikuti, kamu harus takut akan Dia, kamu harus berpegang pada perintah-Nya, suara-Nya harus kamu dengarkan, kepada-Nya harus kamu berbakti dan berpaut.

4. Ulangan 13:4 TUHAN, Allahmu, harus kamu ikuti, kamu harus takut akan Dia, kamu harus berpegang pada perintah-Nya, suara-Nya harus kamu dengarkan, kepada-Nya harus kamu berbakti dan berpaut.

Jadi Philo menekankan kata "berpaut" yang di dalam bahasa Ibrani dikenal dengan istilah D B Q (דבק) untuk menjelaskan penyatuan. Istilah ini juga dipergunakan untuk menggambarkan bagaimana seorang pria meninggalkan orang tuanya dan menyatu dengan seorang wanita di dalam kitab Kejadian (pasal 2: 24).

Di dalam konteks gereja Timur dan gereja Barat mula-mula penyatuan dengan Allah bukanlah konsep yang asing seperti dipaparkan oleh Hali Tjiauw Thuan yang mengkritisi konsep tersebut ${ }^{8}$. Penyatuan sering dikaitkan dengan narasi yang paling diingat yaitu pembaptisan Yesus Kristus oleh Yohanes di sungai Yordan. Pada momen tersebut langit terbuka, Allah Bapa berbicara dari Surga dan Roh Kudus turun dalam rupa burung merpati. Momen itu adalah momen penyatuan sang Manusia Yesus dengan sang Allah Bapa dan Roh Kudus. Penyatuan itu juga nyata ketika di tengah-tengah rutinitas-Nya melayani khalayak ramai, Ia selalu menyediakan waktu khusus untuk bersekutu dengan Bapa-Nya di dalam doa'.

\footnotetext{
${ }^{8}$ Tjiauw Thuan alias Hali, “Analisis Kritis Terhadap Pandangan-Pandangan Unio Mystica Ditinjau Dari Teologia Perjanjian Baru," Veritas 2, no. 2 (2001): 223-37

${ }^{9}$ Ibid. 251.
} 


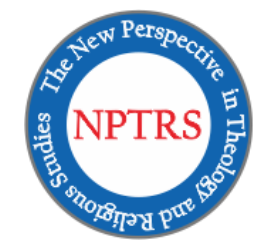

The New Perspective in Theology and Religious Studies

Vol. 2, No. 1 (2021):1-25

http://journalsttcipanas.ac.id/index.php/NPTRS/

p-ISSN 2722-9726, e-ISSN 2722-9718

Published by Cipanas Theological Seminary

Selanjutnya, Origenes yan hidup di tahun 184 sampai 253 Masehi adalah seorang Bapa Gereja, cendekiawan, dan teolog telah mengembangkan gagasan penyatuan kemanusiaan dan keilahian Kristus tersebut. Baginya, penyatuan ini dipahami bagaikan besi yang dipanaskan oleh api. Besi menjadi membara, namun tetap merupakan besi dan api tetap merupakan api. Kedua substansinya masih ada.

Pandangan bahwa Yesus Kristus memiliki hakekat manusia dan Allah menimbulkan berbagai pertanyaan dan tafsiran sehingga muncul berbagai pandangan untuk menyelesaikan hal tersebut. Pertama, seorang tokoh bernama Apollinaris (310-390 Masehi) menyatakan bahwa, Kristus bukan Allah dan bukan manusia, namun sesuatu substansi yang lain. Bagi Apollinaris, Kristus adalah tertiary quid sebagaimana dipaparkan oleh Oliver Crisp dalam bukunya, Divinity and Humanity, the Incarnation Reconsidered. ${ }^{10}$ Apollinaris menyatakan hal itu sebagai penolakan terhadap pemikiran yang juga sudah hadir dari Arianisme. Arianisme menganggap Kristus adalah sepenuhnya Allah yang tidak memiliki substansi manusia sepenuhnya. Juga ada pandangan tentang Yesus Kristus dilihat sebagai manusia yang istimewa dan kemudian diangkat jadi menyamar jadi Allah.

Setelah beberapa lama hal di atas berjalan. kemudian, Bapa Gereja Cyrilus dari Alexandria (tahun Masehi 378-444) merumuskan hubungan antara kemanusiaan dan keilahian Kritus dengan sangat lugas. Tulisannya mengenai hal ini dan surat-suratnya yang ditujukan pada Nestorius dan Yohanes dari Antiochia. Sebagian besar isinya berdasarkan teks John 1:14, Ibrani 1:3, dan Filipi 2:5-8. Dalam kaitan dengan penyelamatan manusia, Cyrillus menyatakan bahwa, Jesus adalah sepenuhnya Allah dan sepenuhnya manusia.

Persoalan mengenai penyatuan dan dua hakekat Kristus itu berlangsung sampai di "selesaikan" dalam konsili Chalcedon di tahun 451: "Yesus adalah sepenuhnya Allah dan sepenuhnya manusia. Ia sepenuhnya seperti manusia lain adalah manusia, kecuali dalam berdosa." Sebelumnya perlu dipahami bahwa, semua isu di antara orang-orang Kristen di masa

${ }^{10}$ Oliver D. Crisp, Divinity and Humanity, Divinity and Humanity (Cambridge UK Cambridge University Press, 2007), https://doi.org/10.1017/cbo9780511805332. 


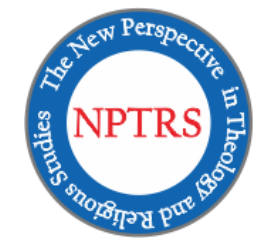

The New Perspective in Theology and Religious Studies

Vol. 2, No. 1 (2021):1-25

http://journalsttcipanas.ac.id/index.php/NPTRS/

p-ISSN 2722-9726, e-ISSN 2722-9718

Published by Cipanas Theological Seminary

itu berakar pada dipergunakan suatu logika yang popular di budaya Yunani-Romawi yaitu logika kategorial yang bertumpu pada pendekatan either-or yang berasal dari Aristoteles.

\section{Logika Aristoteles}

Logika Aristoteles mewarisi konsep dari Plato suatu pandangan bahwa segala substansi adalah kombinasi di antara wujud dan materi (matter). Kemudian, semua wujud dapat dikelompokkan ke dalam kategori-kategori yang memiliki hierarkhi. Karena itulah logika Aristoles dikenal dengan nama logika kategorikal. Pengaruh logika ini sampai abad ke 19 pada Budaya Barat dan Timur Tengah sangat kuat, dengan hanya satu alternatifnya yaitu, dialektika Plato atau juga logika Stoic. ${ }^{11}$

Logika ini memberikan alat bagi manusia yaitu terwujud dalam pernyataan-pernyataan kategorikal (“categorical statements") sebagai berikut: Misalnya ada dua hal yang diungkapkan

- Semua S adalah P

- Sebagian dari S adalah P

- Tidak ada $\mathrm{S}$ yang merupakan $\mathrm{P}$

- Beberapa S adalah bukan P.

Contohnya adalah pertanyaan pertama: semua manusia adalah mamalia. Pernyataan kedua: Sebagian manusia adalah pembangun tempat tinggalnya. Maka dalam logika Aristoteles dapat disimpulkan bahwa, sebagian mamalia adalah pembangun tempat tinggalnya. Pada dasarnya bila dikaji, maka logika ini berdasarkan tiga hal besar:

1. Hukum identitas: A adalah A. A dapat dipecahkan atau dipilah menjadi berbagai fiturnya yang menjadikan identitasnya ini adalah $\mathrm{A}$. Bila B atau $\mathrm{C}$ memiliki seluruh fitur tersebut, maka B atau C tersebut sepenuhnya adalah sama dengan A. Contoh: manusia memiliki empat

\footnotetext{
11 Julie Brumberg-Chaumont. Universal Logic and Aristotelian Logic: Formality and Essence of Logic, Logica Universalis. 9 (2015), 253-278ac, 2015 Springer Basel 1661-8297/15/020253-26, published online, May 31,2015 DOI $10.1007 / \mathrm{s} 11787-015-0123-$
} 


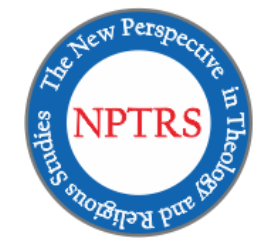

The New Perspective in Theology and Religious Studies

Vol. 2, No. 1 (2021):1-25

http://journalsttcipanas.ac.id/index.php/NPTRS/

p-ISSN 2722-9726, e-ISSN 2722-9718

Published by Cipanas Theological Seminary

fitur dasar yaitu fitur: bisa lapar, bisa berdosa, bisa mati, dan dilahirkan. Bila Kristus memiliki keempat fitur tersebut, maka Kristus adalah sepenuhnya manusia.

2. Hukum Non-Kontradiksi: A adalah tidak bisa "non-A" (bukan A). 'Tidak mungkin suatu fitur pada waktu yang sama termasuk dan tidak termasuk pada suatu subjek ${ }^{12}$ Jadi di dalam daftar fitur tentang manusia di atas, bila ada fitur yang tidak hadir, secara definisi maka subjek secara definisi bukanlah manusia, tetapi sesuatu yang lain. Jadi dalam Kasus Kristus, menurut logika Asristoteles, tidak mungkin bahwa Ia adalah bukan manusia dan sekaligus manusia.

Ketika ada suatu kontradiksi atau paradoks, menurut logika ini maka yang salah adalah sang pengguna logika. Pakar modernpun, Ayn Rand menyatakan 'Contradictions do not exist. Whenever you think you are facing a contradiction, check your premises. You will find that one of them is wrong.' ${ }^{13}$ (kontradiksi tidak benar ada. Bila Anda pikir Anda sedang menghadapi kontradiksi, periksalah premise Anda.)

3. Namun, Aristoteles memberikan juga hukum ketiga, yaitu hukum Tengah yang Terpisah (the law of Excluded Middle): Hukum ini menjelaskan bahwa tidak ada suatu penengah di antara kontradisksi-kontradiksi. Jadi entah kita harus mengafirmasi atau menyangkal salah satu fitur dari apa yang dianggap sebagai paradox dari subjek ${ }^{14}$.

Bagaimana menerapkan hal ini dengan pernyataan bahwa, Kristus adalah Allah dan manusia. Menyatakan Kristus adalah Allah dan manusia membuat dua kategori akan muncul, yaitu Allah dan manusia serta berbagai kemungkinan kaitannya.

1. Kristus adalah manusia

2. Kristus adalah Allah

3. Bagaimana mungkin kedua fitur itu adalah di dalam satu diri? Karena ke"manusia"an dan ke"Ilahi"an termasuk dalam dua kategori yang sangat berbeda.

4. Kecuali bila artinya adalah Allah dan manusia itu sama, apakah demikian?

5. Apakah manusia itu hanya tampilannya, namun karakternya adalah Allah?

$12 \mathrm{http}: / /$ classics.mit.edu/Aristotle/metaphysics.4.iv.html

13 Rand, Ayn. Atlas Shrugged. (New York: Signet, New American Library, 1957). Part I Section VII, hal. 191

$14 \mathrm{http}: / /$ classics.mit.edu/Aristotle/posterior.1..html $\backslash$ part 11 


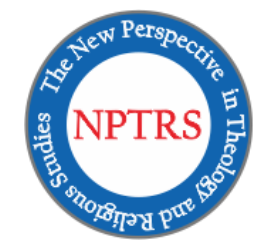

The New Perspective in Theology and Religious Studies

Vol. 2, No. 1 (2021):1-25

http://journalsttcipanas.ac.id/index.php/NPTRS/

p-ISSN 2722-9726, e-ISSN 2722-9718

Published by Cipanas Theological Seminary

6. Apakah kedua kategori itu tercampur, ataukah terkait secara hirarkis?

Karena kerangka logika itu, isu yang dimunculkan terus menerus sejak zaman Gereja awal adalah, bila Kristus adalah wujud Allah dan manusia yang menyatu, apakah substansi kemanusiaanNya dan substansi keallahanNya melebur dan menghasilkan substansi yang baru seperti pemikiran Arian? Mungkinkah substansi keillahian dan substansi kemanusiaan berada bersama di dalam wujud Kristus tanpa tercampur?

Keseluruhan tadi dikembangkan dan coba dijawab oleh teolog-teolog Kristen sampai masa konsili Chalcedon, namun riaknya masih berlanjut. Jadi, secara umum, sebagian terbesar perdebatan di kalangan Kristen terjadi karena suatu akar yang tidak banyak dibahas yaitu, teologi waktu itu dan mungkin juga masih hidup di masa kini sangat bertumpu pada penggunaan logika kategorial yang dasarnya adalah logika yang sangat menekankan konsep either-or atau dualitas yang berakar pada pemikiran Aristoteles ${ }^{15}$.

Sebenarnya salah satu kalangan Kekristenan yang menggunakan logika dan pendekatan yang tidak berakar pada pnedekatan either-or adalah Kekristenan Timur seperti Aleksandria, Kapadokia, Siria, dan Konstantinopel. Selain itu, kalangan mistis Kristiani juga memberi tempat sangat besar pada dimensi misteri Allah yang tidak dapat dikatakan atau diterangkan dengan logika yang mereka kenal. Bahkan, ada di antara mereka yang menekankan pengalaman penyatuan atau kesatuan dengan Allah sebagai peleburan.

Dapat disimpulkan bahwa, pada umumnya, sebagian terbesar penganut iman Kristiani dari Kekristenan Barat tidak menerima konsep penyatuan sebagai peleburan serupa itu apalagi bila dikaitkan dengan diri Kristus. Paham yang diterima adalah bahwa, penyatuan Kristus merupakan persekutuan, keterkaitan, keintiman, namun dua substansi yaitu, kemanusiaan dan keilahian tetap ada seperti yang digambarkan Origenes di atas. Istilah teknisnya adalah Divine Communion. Namun diterima sebagai kebenaran adanya suatu misteri yaitu Kristus adalah

\footnotetext{
${ }^{15}$ Charles J. Kelly, “Aristotelian Logic,” Teaching Philosophy 15, no. 3 (1992): 298-300, https://doi.org/10.5840/teachphil199215355.
} 


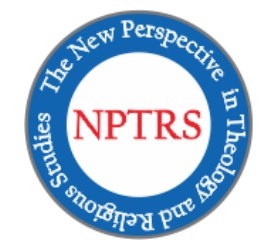

The New Perspective in Theology and Religious Studies

Vol. 2, No. 1 (2021):1-25

http://journalsttcipanas.ac.id/index.php/NPTRS/

p-ISSN 2722-9726, e-ISSN 2722-9718

Published by Cipanas Theological Seminary

sepenuhnya Allah dan sepenuhnya manusia. Hal ini adalah hasil pergumulan panjang dengan menggunakan logika Aristoteles sebagai alat untuk merumuskan kebenaran.

\section{Logika Kejawen}

Isu yang diangkat dan pola pendekatan logika yang serupa itu sangat terasa asing bagi kalangan Asia yang lebih terbiasa dan memilih pendekatan logika yang lain. Dalam logika yang digunakan di Asia apalagi dikalangan Kejawen, sangat ditekankan bahwa,

a. mengenai Allah, manusia sangat terbatas dalam kata dan pemahaman untuk dampat menjelaskannya. Istilah dalam budaya Jawa yang mengungkapkan hal itu adalah tan kena kinaya ngapa, tan kena winirasa yang berarti bahwa "tidak dapat disamakan dengan apaapa dan tak dapat direka-reka dengan pikiran manusia” yang dapat mengungkapkannya. Karena itu, banyak dipergunakan pengungkapan melalui alegori dan metafor ${ }^{16}$. Pemahaman ini mungkin berakar pada corak budaya Jawa yang menekankan hierakhi dan bukan egalitarian, atau apa yang Hofstede, pakar perbandingan budaya disebut dengan istilah power distance. ${ }^{17}$ Artinya, karena Allah begitu berada jauh dari manusia, maka manusia tidak mungkin menangkap pribadi dan karakternya sesuai logika manusia.

b. Sering juga penamaan tentang yang ilahipun beragam dan dibiarkan tidak menyatu. Dapat disimpulkan bahwa gejala itu menunjukkan bahwa, budaya ini mengajarkan multidimensinya Allah dan adanya dimensi misteri dalam hakekat-Nya. Hal ini menunjukkan bahwa, budaya Jawa termasuk budaya yang menurut konsep Hofstede tidak menekankan kepastian, namun lebih merangkul ketidak-pastian. ${ }^{18}$ Bila budaya dan pola pikir Barat lebih menekankan kejelasan, kerincian, dan kepastian-kepastian, maka sebaliknya, budaya Jawa lebih menekankan realitas sebagai multi-dimensi dan cair(liquid) sehingga tidak dapat didefinisikan dengan mudah, apalagi bila menjelaskan mengenai Allah.

\footnotetext{
${ }^{16}$ Bandingkan dengan hasil penelitian Jiani Fan, "Images of Mind, Images of God: Mirror as Metaphor in Chinese Buddhism and Early Mysticism," Buddhist-Christian Studies, 2018, https://doi.org/10.1353/BCS.2018.0017.

17 Geert Hofstede, "Dimensionalizing Cultures: The Hofstede Model in Context," Online Readings in Psychology and Culture 2, no. 1 (2011), https://doi.org/10.9707/2307-0919.1014.

${ }^{18}$ Hofstede.
} 


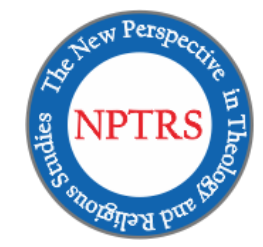

The New Perspective in Theology and Religious Studies

Vol. 2, No. 1 (2021):1-25

http://journalsttcipanas.ac.id/index.php/NPTRS/

p-ISSN 2722-9726, e-ISSN 2722-9718

Published by Cipanas Theological Seminary

Dalam konteks Kejawen, sering peneliti yang bertumpu hanya pada logika Aristoteles dan budaya Barat yang menurut Hofstede sangat menekankan kepastian, kejelasan, dan power distance (jarak kuasa) yang tidak sebesar budaya Jawa menyatakan bahwa pandangan mengenai Allah dalam budaya ini sangat ambivalen. Ada yang menekankan pandangan bahwa Yang Ilahi adalah imanen, sebaliknya ada yang menekankan Yang Ilahi sebagai yang transenden ${ }^{19}$. Dari kedua hal itu muncul gambaran tentang Allah yang diwarnai dimensi misteri yaitu, Allah yang bersahabat, menarik, mesra, dan menakjubkan atau Allah yang menakutkan, dahsyat, dan yang jauh ${ }^{20}$.

c. Kerangka berpikir Kejawen seperti banyak keyakinan lain di Asia secara umum banyak dipengaruhi oleh prinsip non-dualisme ${ }^{21}$. Khususnya di dalam filosofi India, hal ini bukan hal yang asing sebagaimana dipaparkan oleh studi Duquette, mengenai non-dualisme di dalam Sivadvaita Vedanta ${ }^{22}$.

Dalam konteks Kejawen, salah satu ciri dari logika tersebut adalah adanya ruang bagi neither/nor, misalnya yang kita jumpai dalam ungkapan: "tan kena kinaya ngapa" (terjemahan: tidak dapat disamakan dengan apapun), atau misalnya juga ungkapan khas: "ngono yo ngono nanging ojo ngono" (terjemahan: begitu ya begitu namun jangan begitu) Demikian pula, berbagai konsep sering dirumuskan dalam logika bukan ini/bukan itu.

d. Bagaimana menjelaskan mengenai Kristus sebagai Allah dan manusia secara serempak di dalam kerangka pikir Kejawen yang mementingkan Manunggaling Kawula Gusti?

\footnotetext{
${ }^{19}$ Suwardi Endraswara, "Memayu Hayuning Bawana Dalam Perspektif Ekoantropologi Sastra," Susastra, 2017.

${ }^{20}$ Josephine Klein, "The Experience of the Holy: Mysterium Tremendum et Fascinans," in Jacob's Ladder, New York, NY: Routledge, 2018, https://doi.org/10.4324/9780429476297-4.

${ }^{21}$ Frank J. Hoffman, "Non-Dual Awareness and Logic," Asian Philosophy 11, no. 2 (2001): 125-32, https://doi.org/10.1080/09552360120087886.

${ }^{22}$ Jonathan Duquette, "Reading Non-Dualism in Śivādvaita Vedānta: An Argument from the Śivādvaitanirṇaya in Light of the Śivārkamaṇidīpikā," Journal of Indian Philosophy 44, no. 1 (March 1, 2016): 67-79, https://doi.org/10.1007/s10781-014-9231-x.
} 


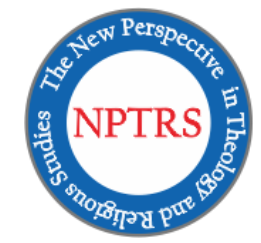

The New Perspective in Theology and Religious Studies

Vol. 2, No. 1 (2021):1-25

http://journalsttcipanas.ac.id/index.php/NPTRS/

p-ISSN 2722-9726, e-ISSN 2722-9718

Published by Cipanas Theological Seminary

Keyakinan Kejawen adalah cerminan atau hasil dari dorongan manusia mencapai kebahagiaan dan keselamatan baik di masa hidup maupun sesudahnya. ${ }^{23}$ Istilah manunggaling kawula gusti berarti penyatuan. Kepelbagaian di antara aliran Kejawen sebagai keyakinan asli (indigenous belief) atau agama rakyat sendiri nyata, juga di dalam konsep manunggaling kawula Gusti. Apalagi banyak hal tidak diterangkan tuntas karena, dorong untuk menuntaskan pemahaman tentang Allah kalah dengan dorongan untuk menggambarkan Allah atau hidup dan penyatuan dengannya dalam bahasa alegoris atau metafor. Penggunaan modus ekspresi seperti itu secara implisit menunjukkan sikap tahu batas dan membuka ruang untuk perbedaan perspektif berdasarkan kesadaran atas kefanaan dan keterbatasan manusia. Tidakkah hidup saja hanya dilihat sebagai proses berhenti sejenak untuk minum air.

Menurut Suwardi Endraswara, ahli dalam Kejawen Sufi mistik dan budaya Jawa, ada dua jenis pemahaman mengenai manunggaling kawula gusti. Pemahaman pertama adalah manunggaling kawula Gusti sebagai peleburan antara Yang Ilahi dan manusia, sedangkan paham yang kedua adalah keterpautan dan keintiman atau penyatuan antara manusia dan Allah tanpa peleburan ${ }^{24}$. Kesamaan keduanya adalah bahwa, penyatuan dapat dicapai dengan manusia memahaminya, menghayatinya, serta menjalani tahap-tahapnya yang menurut tiap aliran kebathinan berbeda-beda. Misalnya, bila dipercaya bahwa, penyatuan antara yang ilahi dan manusia itu dalam paham yang kedua, maka caranya adalah Penyatuan manusia dengan Tuhan dengan salah satu dari dua cara yakni mendekatkan diri dengan ritual ibadah dan ajaran mistis ${ }^{25}$.

\footnotetext{
${ }^{23}$ Dicky Dominggus, "Kemanunggalan Dalam Yohanes 15:7 Sebagai Misi Kontekstual Kepada Penganut Kejawen," VIisio Deii 1, no. 2 (2019): 178-99, https://doi.org/10.35909/visiodei.v1i2.53.

${ }^{24}$ Suwardi Endraswara, Mistik Kejawen: Sinkretisme, Simbolisme dan Sufisme dalam Budaya Spiritual Jawa, (YogyakartaL Penerbit Narasi, 2006), hal. 49.

${ }^{25}$ A. H. Utomo, "Tauhid Al-Wujud Syeikh Siti Jenar Dan Unio Mystica Bima," Jurnal Filsafat 40, no. 2 (2017): 116-27, https://doi.org/10.22146/jf.23204.
} 


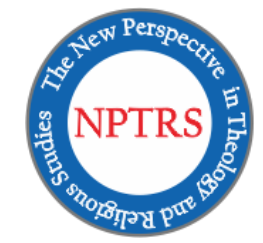

The New Perspective in Theology and Religious Studies

Vol. 2, No. 1 (2021):1-25

http://journalsttcipanas.ac.id/index.php/NPTRS/

p-ISSN 2722-9726, e-ISSN 2722-9718

Published by Cipanas Theological Seminary

Zoetmulder menunjukkan dalam karya klasiknya bahwa, dasar dari manunggaling kawula Gusti adalah pada pemahaman filsafat monistik dan pantheism yang hadir pada filsafat Jawa terkesan ambivalen atau tercampur. Monistik mengisyaratkan pemahaman bahwa dalam kenyataan segalanya hanya satu. Sendangkan pantheism menunjukkan dunia adalah bagian kehadiran Tuhan ada di dalam segalanya ${ }^{26}$.

Dalam bukunya Bambang Noorsena memaparkan bahwa, Yesus sebagai Sang Manunggaling Kawula Gusti sejati bukan berarti peleburan hakekat kemanusiaan-Nya dan Keilahian-Nya. Menurut daging dan menurut Roh, dilahirkan dan tidak dilahirkan, lahir dari Maria dan lahir dari Allah yang menurut Noorsena dalam pola budaya spiritual Jawanya adalah mungguh ing daging lan mungguhing roh, pintura nora pinutrake mijil saka Maryam lan mijil saka Allah, loro-loroing atunggil ${ }^{27}$.

Dicky Dominggus dalam Kemanunggalan dalam Yohanes 15:7 Sebagai Misi Kontekstual Kepada Penganut Kejawen ${ }^{28}$ yang menunjukkan kesamaan antara kemanunggalan dalam beberapa contoh di Alkitab dengan kemanunggalan dalam Kejawen, namun juga menunjukkan perbedaan-perbedaan bila menggunakan logika Aristoteles atau biner.

\section{Logika Sentensial}

Apakah yang dimaksud dengan logika sentensial? Logika sentensial atau juga dikenal dengan nama Categorical Logic adalah salah satu cabang logika yang mengkaji cara menghubungkan atau memodifikasi suatu pernyataan, atau kalimat untuk membentuk pernyataan atau kalimat yang lebih rumit serta juga hubungan nalar dan sifatnya yang lebih utuh akibat penggabungan karakteristik dan sifat-sifat sebagai hasil dari metode penggabungan atau

\footnotetext{
${ }^{26}$ David Hicks and P. J. Zoetmulder, "Pantheism and Monism in Javanese Suluk Literature: Islamic and Indian Mysticism in an Indonesian Setting.," Pacific Affairs 69, no. 4 (1996): 600, https://doi.org/10.2307/2761214.

${ }^{27}$ Bambang Noorsena, Menyongsong Sang Ratu Adil: Perjumpaan Iman Kristen Dan Kejawen, 1st ed. (Yogyakarta: Andi Offset, 2003). hal 17

${ }^{28}$ Dominggus, "Kemanunggalan Dalam Yohanes 15:7 Sebagai Misi Kontekstual Kepada Penganut Kejawen.” Visio Dei, 2019, Vol 1. (2)/
} 


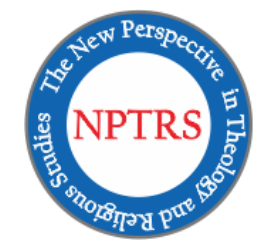
The New Perspective in Theology and Religious Studies

Vol. 2, No. 1 (2021):1-25

http://journalsttcipanas.ac.id/index.php/NPTRS/

p-ISSN 2722-9726, e-ISSN 2722-9718

Published by Cipanas Theological Seminary

perubahan tersebut. ${ }^{29}$ Tujuan logika ini adalah menguji atau menyatakan kebenaran yang dimuat dalam suatu pernyataan dan kalimat. Cara menggunakan logika ini adalah dengan menggunakan simbol-simbol ${ }^{30}$ sehingga memiliki sintaks sendiri.

\subsection{Asal usul Logika sentensial ${ }^{31}$}

Sentential Logic dibuat pada tahun 225 SM. oleh ahli logika Yunani kuno Chrysippus. Pengetahuan tentang logika itu hilang pada Abad Kegelapan, tetapi ditemukan kembali oleh filsuf Prancis Abelard pada abad ke-12. Sistem tabel kebenaran untuk Sentential Logic ditemukan pada tahun 1902 oleh ahli logika Amerika Charles Peirce untuk menampilkan bagaimana kebenaran dari beberapa kalimat akan mempengaruhi kebenaran kalimat lainnya. Tabel kebenaran ditemukan kembali secara independen oleh Ludwig Wittgenstein dan Emil Post.

Sistem pembuktian untuk Sentential Logic dikembangkan pada tahun 1879 oleh ahli logika Jerman Gottlob Frege untuk memungkinkan membuat pembuktian yang serupa dengan pembuktian dalam geometri bidang ketika aturan kesimpulan dan aksioma digunakan. Bukti adalah daftar pernyataan/kalimat, urutan langkah.

Sistem pembuktian untuk Sentential Logic sering disebut Sentential Calculus. Jika Sentential Logic menggunakan nama Propositional Logic, maka sistem pembuktiannya disebut Propositional Calculus.

Setiap argumen yang dapat terbukti valid dengan metode tabel kebenaran juga merupakan argumen yang kesimpulannya dapat dibuktikan dari premisnya dengan menggunakan aksioma dan aturan inferensi dalam sistem pembuktian. Properti Logika

\footnotetext{
${ }^{29}$ Internet Encyclopaedia of Philosophy: a Peer Review Academic Resource: Propositional Logic https://iep.utm.edu/prop-log/

${ }^{30}$ Daniel J. Velleman, "Sentential Logic," in How to Prove It (Cambridge, UK: Cambridge University Press, 2011), 8-54, https://doi.org/10.1017/cbo9780511808234.003.

${ }^{31}$ Bradley H. Dowden. Diakses dari sumber Internet. url: https://human.libretexts.org/Bookshelves/Philosophy/Book\%3A_Logical_Reasoning_(Dowden)/11\%3A_Logical_ Form_and_Sentential_Logic/11.04\%3A_Sentential_Logic/11.4.04\%3A_History_of_Sentential_Logic
} 
The New Perspective in Theology and Religious Studies

Vol. 2, No. 1 (2021):1-25

http://journalsttcipanas.ac.id/index.php/NPTRS/

p-ISSN 2722-9726, e-ISSN 2722-9718

Published by Cipanas Theological Seminary

Sentensial ini disebut kelengkapan. Kelengkapan Kalkulus Sentensial pertama kali dibuktikan oleh ahli logika Amerika Emil Post pada tahun 1921.

Sentential Logic juga memiliki properti kebalikannya, yaitu setiap argumen yang dapat dibuktikan juga valid. Jadi, validitas dan pembuktian datang pada hal yang sama dalam arti himpunan argumen yang valid juga merupakan himpunan argumen yang kesimpulannya dapat dibuktikan dari premis-premisnya.

\subsection{Penggunaan dan semantik dalam Logika Sentensial}

Bagaimana logika sentensial menyampaikan suatu proposisi. Contohnya: Allah adalah pencipta dan manusia adalah ciptaan Tuhan.

a. Dalam kalimat atau proposisi tersebut terdapat dua hal yang disampaikan. Pertama, Allah adalah pencipta. Kedua, manusia adalah ciptaan.

b. Kedua kalimat tadi dapat sama-sama benar dan sama-sama salah atau salah satu benar dan salah satu salah.

c. Kalimat Allah adalah pencipta dapat disimbolkan sebagai P. Kalimat Manusia adalah ciptaan bisa disimbolkan sebagai Q

d. Bagaimana menghubungkan kedua pernyataan tersebut dan meneliti apakah hal itu logis atau tidak? Logika sentensial menggunakan beberapa symbol

\begin{tabular}{|c|c|c|c|}
\hline $\begin{array}{c}\text { Hubungan yang } \\
\text { mungkin }\end{array}$ & Nama & Makna & Simbol 1 \\
\hline Ke 1 & Penghubung & Dan & $\&$ \\
\hline Ke 2 & Pemisah & Atau & V \\
\hline Ke 3 & Negasi & Bukan & $\sim$ \\
\hline Ke 4 & Bersyarat & Bila/maka & $\rightarrow$ \\
\hline Ke 5 & Syarat ganda & Bila dan hanya bila & $\leftrightarrow$ \\
\hline
\end{tabular}




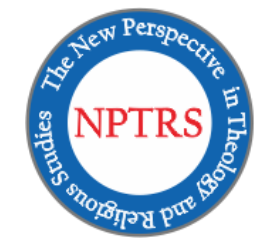

The New Perspective in Theology and Religious Studies

Vol. 2, No. 1 (2021):1-25

http://journalsttcipanas.ac.id/index.php/NPTRS/

p-ISSN 2722-9726, e-ISSN 2722-9718

Published by Cipanas Theological Seminary

5.3 Tabel kebenaran Logika Sentensial ${ }^{32}$

Alat yang sangat efisien dan efektif dalam logika sentensial adalah apa yang dikenal sebagai tabel kebenaran. Melalui berbagai symbol, logika sentensial dapat menyatakan kebenaran atau ketidak-benaran/kesalahan. Lebih lanjut lagi, salah satu keunggulan logika ini adalah dengan logika ini membuat beberapa tabel kebenaran. Contohnya di bawah ini yang memberikan gambaran tentang cara kerja negasi:

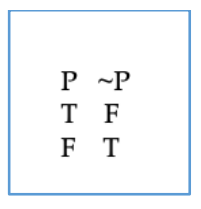

Tabel 1.

Tabel ini menyiratkan, ada dua proposisi yaitu $\mathrm{P}$ dan lawan dari $\mathrm{P}$ yang digambarkan dengan symbol $\sim \mathrm{P}$. Di baris kedua dideskripsikan, bila $\mathrm{P}$ adalah benar (True $=\mathrm{T}$ ), maka $\sim P$ adalah keliru $($ False $=F)$. Sebaliknya bila $P$ adalah false $(F)$ maka yang lawan $P$ adalah benar $(\mathrm{T})$.

Dalam kaitan dengan penyatuan kemanusiaan dan keilahian dalam Kristus, maka dalam logika sentensial bagian ini dapat dijelaskan bahwa

1. Ada dua pernyataan: $P$ dan $\sim P$

2. P: Kristus adalah penyatuan Allah dan manusia

3. $\sim$ P: Kristus adalah bukan penyatuan Allah dan manusia

4. Maka ada dua kemungkinan

a. Bila pernyataan bahwa Kristus adalah penyatuan Allah dan manusia adalah benar (T) maka, pernyataan Kristus adalah bukan penyatuan Allah dan Manusia adalah salah $(\mathrm{F})$

\footnotetext{
32 Bradley H. Dowden. Truth tables. url: https://human.libretexts.org/Bookshelves/Philosophy/Book\%3A_Logical_Reasoning_(Dowden)/11\%3A_Logical Form_and_Sentential_Logic/11.04\%3A_Sentential_Logiac/11.4.01\%3A_Truth_Tables
} 


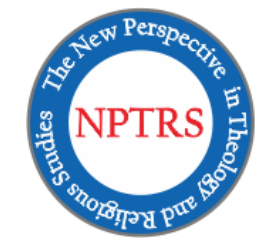

The New Perspective in Theology and Religious Studies

Vol. 2, No. 1 (2021):1-25

http://journalsttcipanas.ac.id/index.php/NPTRS/

p-ISSN 2722-9726, e-ISSN 2722-9718

Published by Cipanas Theological Seminary

b. Bila pernyataan bahwa Kristus adalah penyatuan Allah dan manusia adalah salah (F) maka, pernyataan Kristus adalah bukan penyatuan Allah dan Manusia adalah benar $(\mathrm{T})$

Selanjutnya dalam logika sentensial terdapat tabel kebenaran tentang bagaimana ' $v$ ' memengaruhi nilai kebenaran kalimat:

\begin{tabular}{|ccc}
\hline \multicolumn{2}{|c}{ P Q } & P v \\
\hline T & T & T \\
T & F & T \\
F & T & T \\
F & F & F \\
\hline
\end{tabular}

Tabel 2. $(\mathrm{v}=\mathrm{atau})$

Dalam kaitan dengan penyatuan kemanusiaan dan keilahian dalam Kristus, maka dalam logika sentensial dapat dijelaskan bahwa

1. Ada tiga pernyataan: $\mathrm{P}, \mathrm{Q}$, dan $\mathrm{PvQ}$

2. P: Kristus adalah penyatuan ketika Allah dan manusia melebur

3. Q: Kristus adalah penyatuan ketika Allah dan manusia terpaut

4. PvQ: Kristus adalah penyatuan Allah dan Manusia atau Kristus adalah peleburan antara Allah dan manusia

a. Bila pernyataan bahwa Kristus adalah penyatuan ketika Allah dan manusia melebur adalah benar $(\mathrm{T})$ dan, pernyataan Kristus adalah penyatuan ketika Allah dan Manusia terpaut adalah benar, maka Kristus adalah benar perleburan atau penyatuan Allah dan Manusia (T).

b. Bila pernyataan bahwa Kristus adalah penyatuan ketika Allah dan manusia melebur adalah salah (F) dan, pernyataan Kristus adalah penyatuan ketika Allah dan Manusia terpaut adalah salah (F), maka Kristus adalah benar peleburan namun bukan penyatuan $(\mathrm{T})$.

c. Bila pernyataan bahwa Kristus adalah penyatuan ketika Allah dan manusia melebur adalah benar $(\mathrm{T})$ dan, pernyataan Kristus adalah penyatuan ketika Allah 


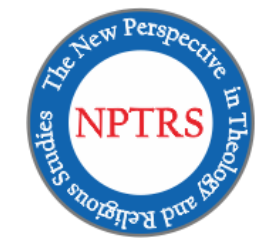

The New Perspective in Theology and Religious Studies

Vol. 2, No. 1 (2021):1-25

http://journalsttcipanas.ac.id/index.php/NPTRS/

p-ISSN 2722-9726, e-ISSN 2722-9718

Published by Cipanas Theological Seminary

dan Manusia terpaut adalah salah (F), maka salah satu pernyataan akan benar entah Kristus adalah sebagai peleburan atau sebagai penyatuan (T).

d. Bila pernyataan bahwa Kristus adalah penyatuan ketika Allah dan manusia melebur adalah salah (F) dan, pernyataan Kristus adalah penyatuan ketika Allah dan Manusia terpaut adalah salah (F), maka pernyataan Kristus adalah sebagai peleburan adalah salah atau Kristus sebagai penyatuan juga salah (F).

Selanjutnya, masih ada Tabel kebenaran untuk \& (dan)

\begin{tabular}{|lll|}
\hline \multicolumn{2}{|c|}{ P Q } & P \& $Q$ \\
\hline T & T & T \\
T & F & F \\
F & T & F \\
F & F & F \\
\hline
\end{tabular}

Tabel $3(\&=$ dan $)$

Ada tiga pernyataan: $\mathrm{P}, \mathrm{Q}$, dan $\mathrm{P} \& \mathrm{Q}$

P: Kristus adalah penyatuan ketika Allah dan manusia melebur

Q: Kristus adalah penyatuan ketika Allah dan Manusia terpaut

P \& Q: Kristus adalah penyatuan Allah dan Manusia dan Kristus adalah peleburan antara Allah dan manusia

Tanpa mengulangi secara rinci pemaparan seperti di tabel sebelumnya, maka dengan meneliti baris pertama saja akan didapat pemahaman yang dapat menjawab persoalan dalam artikel ini. Dalam baris pertama pada logika sentensial terbaca bahwa bila pernyataan Krisus adalah Allah dan manusia yang menyatu merupakan kebenaran dan pernyataan Kristus adalah Allah dan manusia yang melebur juga merupakan kebenaran, maka Kristus adalah Allah dan manusia yang menyatu dan melebur merupakan kebenaran.

Kemudian, berikut ini adalah tabel kebenaran untuk $\rightarrow$ (jika) 
The New Perspective in Theology and Religious Studies

Vol. 2, No. 1 (2021):1-25

http://journalsttcipanas.ac.id/index.php/NPTRS/

p-ISSN 2722-9726, e-ISSN 2722-9718

Published by Cipanas Theological Seminary

\begin{tabular}{ccc}
$\mathrm{P} Q$ & $\mathrm{P} \rightarrow \mathrm{Q}$ \\
& \\
\hline $\mathrm{T}$ & $\mathrm{T}$ & $\mathrm{T}$ \\
$\mathrm{T}$ & $\mathrm{F}$ & $\mathrm{F}$ \\
$\mathrm{F}$ & $\mathrm{T}$ & $\mathrm{T}$ \\
$\mathrm{F}$ & $\mathrm{F}$ & $\mathrm{T}$
\end{tabular}

Tabel 4. $(\rightarrow=$ jika $)$

Ada tiga pernyataan: $\mathrm{P}, \mathrm{Q}$, dan $\mathrm{P} \rightarrow \mathrm{Q}$

P: Kristus adalah penyatuan ketika Allah dan manusia melebur

Q: Kristus adalah penyatuan ketika Allah dan Manusia terpaut

$\mathrm{P} \rightarrow \mathrm{Q}$ : Kristus adalah penyatuan Allah dan Manusia yang melebur jika Kristus adalah penyatuan antara Allah dan manusia ketika Allah dan manusia saling terpaut.

Tanpa mengulangi secara rinci pemaparan seperti di tabel 1 dan 2 sebelumnya, maka dengan meneliti baris pertama saja akan didapat pemahaman yang dapat menjawab persoalan dalam artikel ini. Dalam baris pertama pada tabel kebenaran 4 dari logika sentensial terbaca bahwa bila pernyataan Krisus adalah Allah dan manusia yang menyatu merupakan kebenaran maka akan berimplikasi bahwa pernyataan Kristus adalah Allah dan manusia yang melebur juga merupakan kebenaran, maka Kristus adalah Allah dan manusia yang menyatu dan sekaligus melebur. Di titik inilah letak kecanggihan logika proposisional, karena dapat menganalisis problematika dalam setiap pernyataan yang tidak dimiliki oleh logika kategorikal Aristoteles.

Masih ada hal yang sangat penting dalam konsep logika sentensial yang tersebut di atas, masih termuat adanya konsep betweenness/neitherness/bothness di dalamnya, yang berbeda dalam logika biner Aristotelian. Hal ini terlihat dalam adanya simbol untuk hubungan yang kelima seperti dipaparkan di atas, yaitu syarat yang ganda.

1. pernyataan-pernyataan dari bentuk "bukan P dan juga bukan Q" atau pernyataan neither/nor (bukan ini bukan itu).

2. Menyebutkan bahwa baik $P$ dan $Q$ adalah salah adalah sama dengan menyebutkan bahwa tidak satupun yang benar. 
Vol. 2, No. 1 (2021):1-25

http://journalsttcipanas.ac.id/index.php/NPTRS/

p-ISSN 2722-9726, e-ISSN 2722-9718

Published by Cipanas Theological Seminary

3. Hal ini dapat dinyatakan sebagai berikut: "Bukan salah satu atau keduanya dari P dan Q yang benar," yang merupakan negasi dari "Paling sedikit satu dari P dan Q adalah benar" - dalam simbol, " (PvQ)", dan hal tersebut dapat diverifikasi dengan suatu tabel kebenaran.

\begin{tabular}{|c|c|c|c|}
\hline $\mathrm{P}$ & $\mathrm{Q}$ & $\mathrm{PvQ}$ & $\sim(\mathrm{PvQ})$ \\
\hline $\mathrm{T}$ & $\mathrm{T}$ & $\mathrm{T}$ & $\mathrm{F}$ \\
\hline $\mathrm{T}$ & $\mathrm{F}$ & $\mathrm{T}$ & $\mathrm{F}$ \\
\hline $\mathrm{F}$ & $\mathrm{T}$ & $\mathrm{T}$ & $\mathrm{F}$ \\
\hline $\mathrm{F}$ & $\mathrm{F}$ & $\mathrm{F}$ & $\mathrm{T}$ \\
\hline
\end{tabular}

Tabel 5. $\sim(\mathrm{PvQ})$

Adapun implikasinya adalah seperti pada uraian tabel 3, namun dalam versi negasinya. Artinya: pernyataan bahwa Kristus adalah sekaligus bukan penyatuan Allah atau manusia dimana mereka terpaut namun juga bukan penyatuan dimana terjadi peleburan.

5. Selain itu, masih terdapat dasar pemikiran yang sama di balik kaidah lainnya, yang menyatakan bahawa " P v $Q$ " adalah ekivalen dengan " (P\&Q)". 33

\begin{tabular}{|c|c|c|c|}
\hline $\mathrm{P}$ & $\mathrm{Q}$ & $\mathrm{P} \& \mathrm{Q}$ & $\sim(\mathrm{P} \& \mathrm{Q})$ \\
\hline $\mathrm{T}$ & $\mathrm{T}$ & $\mathrm{T}$ & $\mathrm{F}$ \\
\hline $\mathrm{T}$ & $\mathrm{F}$ & $\mathrm{F}$ & $\mathrm{T}$ \\
\hline $\mathrm{F}$ & $\mathrm{T}$ & $\mathrm{F}$ & $\mathrm{T}$ \\
\hline $\mathrm{F}$ & $\mathrm{F}$ & $\mathrm{F}$ & $\mathrm{T}$ \\
\hline
\end{tabular}

Tabel 6. $\sim(P \& Q)$

${ }^{33} \mathrm{https}$ ///stackoverflow.com/questions/5201034/translating-neither-nor-into-a-mathematical-logical-expression 
The New Perspective in Theology and Religious Studies

Vol. 2, No. 1 (2021):1-25

http://journalsttcipanas.ac.id/index.php/NPTRS/

p-ISSN 2722-9726, e-ISSN 2722-9718

Published by Cipanas Theological Seminary

Adapun implikasinya adalah seperti pada uraian tabel 4, namun dalam versi negasinya. Artinya: pernyataan bahwa Kristus adalah sekaligus bukan penyatuan Allah dan manusia yang saling terpaut namun juga bukan penyatuan Allah dan manusia yang berupa peleburan.

Dengan pemikiran yang serupa, maka jika kita menuliskan simbol non-dualisme (manunggal/jatidiri atau substansi yang lebur) sebagai $\mathrm{P}$, dan dualisme (substansi atau jatidiri yang terpisah antara kawula dan Gusti) sebagai Q, maka, Kristus sebagai Sang Manunggaling Kawula Gusti dapat dituliskan: $\sim\left(P_{v}\right.$ Q). Artinya, Kristus sebagai Sang Manunggaling Kawula Gusti bukanlah Allah yang menyatu dengan manusia sampai melebur dan bukan juga Allah yang menyatu dengan manusia dengan berpaut.

Hal ini mudah dipahami oleh pendukung non-dualisme seperti penganut Kejawen, bahkan mistikus sufi dan para pendukung mazhab dualism sebagai misteri. Dengan singkat, kebenaran bukanlah harus dijelaskan sebagai "ini" atau "itu” yang salah satunya merupakan "bukan kebenaran." Kebenaran dapat dipahami sebagai "bukan ini dan bukan itu” atau "ya ini dan ya itu juga." Bahkan, mereka menganggap hal yang benar adalah "di antara ini dan itu" yang khas merupakan pola pikir dan logika mereka. Hal ini diyakini lebih mewakili kenyataan dan pengalaman yang manusia tangkap, sedangkan pendekatan logika "ini atau itu" dipandang tidak utuh dan terlalu menyederhanakan serta tidak memberi ruang untuk kompleksitas. Serupa dengan pemikiran ini, maka dalam pengalaman sehari-hari ada kondisi antara, misalnya antara siang (A) dan malam (B), kita mengenal senja atau fajar.

Sepintas lalu, tampaknya logika sentensial dengan proposisi bukan ini-bukan itu (neither/nor) tidak berkontradiksi dengan logika Aristotel, namun sebenarnya ini melibatkan konsep yang lebih rumit sebagai diungkapkan oleh Heald yang menyatakan:

"It is widely accepted that "neither true nor false" can be regarded as the third logic state. Many systems, however, have erroneously assigned the " don't know " state to "neither 


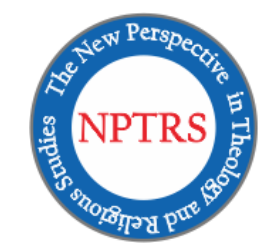

The New Perspective in Theology and Religious Studies

Vol. 2, No. 1 (2021):1-25

http://journalsttcipanas.ac.id/index.php/NPTRS/

p-ISSN 2722-9726, e-ISSN 2722-9718

Published by Cipanas Theological Seminary

true nor false". ${ }^{34}$ (Biasanya diterima umum bahwa, "Bukan benar atau salah" dapat dianggap sebagai kondisi logis yang ketiga. Banyak system karena itu, menggunakan istilah "tidak tahu" untuk menjelaskan kondisi "bukan benar atau salah")

Jadi, dapat disimpulkan bahwa dalam logika sentensial dimungkinkan pemahaman bahwa manusia serempak bukan disatukan dengan Sang Khalik, diwarnai, atau dipertajam bagaikan pedang dibakar api yaitu pada saat yang sama tetap berbeda dengan Sang Khalik serta bukan juga mengalami peleburan sebagaimana dipahami dalam beberapa konsep Kejawen atau Sufi serta mistikus Barat tertentu.

Dari perspektif ini logika dari Manunggaling kawula Gusti masuk akal. Dari kerangka pikir teologi, logika ini setia pada perumusan Chalcedon yaitu menolak pandangan dualis Appolinari atau Arian yang memang sudah ditolak Gereja di masanya.

Kegunaan logika sentensial ini, Gereja dapat memperjelas diri Kristus terutama kekhasannya yang membuat manusia tidak dapat memamparkannya secara sederhana dan logika biasa yang masuk akal.

\section{Kesimpulan}

Studi ini adalah bagian dari pemikiran awal untuk memformulasikan logika yang khas Nusantara, khususnya dalam menelaah konsep Jesus sebagai Sang Manunggaling Kawula Gusti dalam Budaya Jawa. Bagaimanapun juga, tidak dapat diabaikan pendapat Hegel yang menyatakan bahwa menghubungkan metafisika dan logika adalah merupakan keniscayaan. Namun, lebih dalam lagi perlu disadari bahwa, mencoba memahami kemanunggalan substansi kemanusiaan Kristus dan keilahian-Nya membuat siapa yang mengusahakan hal itu memiliki pilihan yaitu pertama, menggunakan logika Aristoteles yang biner berakhir pada mengakui perlunya ada kategori yang disebut dengan "hal yang tidak kita tahu." Pilihan kedua adalah,

\footnotetext{
34 Graeme Heald. Why the logic state 'neither true nor false' has been incorrectly assigned. url: https://www.researchgate.net/publication/319328333_Why_the_logic_state_\%27neither_true_nor_false $\% 27$ has_ been_incorrectly_assigned
} 


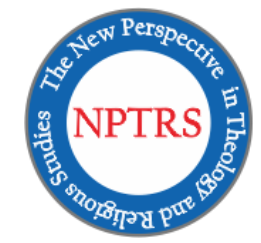

The New Perspective in Theology and Religious Studies

Vol. 2, No. 1 (2021):1-25

http://journalsttcipanas.ac.id/index.php/NPTRS/

p-ISSN 2722-9726, e-ISSN 2722-9718

Published by Cipanas Theological Seminary

menggunakan logika sentensial untuk mencoba menjelaskan lebih tuntas. Logika ini dapat menjelaskan pemahaman Manunggaling Kawula Gusti dalam dua versinya, namun pada akhirnya penggunakan logika ini sulit dipopulerkan karena, sebagian besar manusia tidak terbiasa menggunakannya.

Dengan cara menjelaskan logika sentensial, diharapkan artikel ini dapat memperluas cakrawala pemikiran, terutama bagi mereka yang berusaha melakukan membagikan imannya, melakukan kontekstualisasi, serta berdialog dengan kesediaan terlebih dulu memahami mitra dialog dan membagikan gagasan tentang Yesus, Sang Mesias kepada mereka, yaitu para penganut Kejawen dan umat lain di Nusantara yang tentu juga berusaha membagikan pemahaman dan penngalaman mereka.

\section{Daftar Pustaka}

Crisp, Oliver D. Divinity and Humanity. Divinity and Humanity. Cambrid: Cambridge University Press, 2007. https://doi.org/10.1017/cbo9780511805332.

Dominggus, Dicky. "Kemanunggalan Dalam Yohanes 15:7 Sebagai Misi Kontekstual Kepada Penganut Kejawen.” VIisio Deii 1, no. 2 (2019): 178-99. https://doi.org/10.35909/visiodei.v1i2.53.

Duquette, Jonathan. "Reading Non-Dualism in Śivādvaita Vedānta: An Argument from the Śivādvaitanirṇaya in Light of the Śivārkamaṇidīpikā.” Journal of Indian Philosophy 44, no. 1 (March 1, 2016): 67-79. https://doi.org/10.1007/s10781-014-9231-x.

Endraswara, Suwardi. "Memayu Hayuning Bawana Dalam Perspektif Ekoantropologi Sastra.” Susastra, 2017.

Fan, Jiani. "Images of Mind, Images of God: Mirror as Metaphor in Chinese Buddhism and Early Mysticism.” Buddhist-Christian Studies, 2018. https://doi.org/10.1353/BCS.2018.0017.

Hadiwijaya. Tokoh-Tokoh Kejawen. 1st ed. Yogyakarta: Eulo Book, 2010.

Hali, Tjiauw Thuan A L I A S. "Analisis Kritis Terhadap Pandangan-Pandangan Unio Mystica Ditinjau Dari Teologia Perjanjian Baru." Veritas 2, no. 2 (2001): 223-37. https://www.academia.edu/34894305/ANALISIS_KRITIS_TERHADAP_PANDANGAN_PAND ANGAN_UNIO_MYSTICA_DITINJAU_DARI_TEOLOGIA_PERJANJIAN_BARU.

Hicks, David, and P. J. Zoetmulder. "Pantheism and Monism in Javanese Suluk Literature: Islamic and 


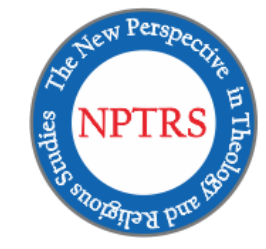

The New Perspective in Theology and Religious Studies

Vol. 2, No. 1 (2021):1-25

http://journalsttcipanas.ac.id/index.php/NPTRS/

p-ISSN 2722-9726, e-ISSN 2722-9718

Published by Cipanas Theological Seminary

Indian Mysticism in an Indonesian Setting." Pacific Affairs 69, no. 4 (1996): 600. https://doi.org/10.2307/2761214.

Hoffman, Frank J. "Non-Dual Awareness and Logic." Asian Philosophy 11, no. 2 (2001): 125-32. https://doi.org/10.1080/09552360120087886.

Hofstede, Geert. "Dimensionalizing Cultures: The Hofstede Model in Context." Online Readings in Psychology and Culture 2, no. 1 (2011). https://doi.org/10.9707/2307-0919.1014.

Kelly, Charles J. “Aristotelian Logic.” Teaching Philosophy 15, no. 3 (1992): 298-300. https://doi.org/10.5840/teachphil199215355.

Klein, Josephine. "The Experience of the Holy: Mysterium Tremendum et Fascinans.” In Jacob's Ladder. New York, NY: Routledge, 2018. https://doi.org/10.4324/9780429476297-4.

Noorsena, Bambang. Menyongsong Sang Ratu Adil: Perjumpaan Iman Kristen Dan Kejawen. 1st ed. Yogyakarta: Andi Offset, 2003.

Saut, David. “Ada 187 Organisasi Dan 12 Juta Penghayat Kepercayaan Di Indonesia.” Detiknews. November 9, 2017. https://news.detik.com/berita/d-3720357/ada-187-organisasi-dan-12-jutapenghayat-kepercayaan-di-indonesia.

Utomo, A. H. "Tauhid Al-Wujud Syeikh Siti Jenar Dan Unio Mystica Bima.” Jurnal Filsafat 40, no. 2 (2017): 116-27. https://doi.org/10.22146/jf.23204.

Velleman, Daniel J. “Sentential Logic.” In How to Prove It, 8-54. Cambridge, UK: Cambridge University Press, 2011. https://doi.org/10.1017/cbo9780511808234.003.

Zoetmoelder. Manunggaling Kawula-Gusti : Pantheisme Dan Monism Dalam Sastra Suluk Jawa : Suatu Studi Filsafat. Cet. 2. Jakarta: Gramedia Pustaka Utama, 2000.

https://stackoverflow.com/questions/5201034/translating-neither-nor-into-a-mathematical-logicalexpression 